\title{
Pain in photodynamic therapy: mechanism of action and management strategies
}

\author{
Dor na terapia fotodinâmica: mecanismo de ação e estratégias de manejo
}

\author{
Yuri Nogueira Chaves ${ }^{1}$ \\ Ane Beatriz Mautari Niwa ${ }^{3}$ \\ Ciro Festa Neto ${ }^{5}$
}

\author{
Luis Antônio Torezan ${ }^{2}$ \\ José Antônio Sanches Junior ${ }^{4}$
}

\begin{abstract}
Photodynamic therapy involves administration of a photosensitizing drug and its subsequent activation by irradiation with a light source at wavelengths matching the absorption spectrum of the photosensitizer. In many countries around the world, topical photodynamic therapy has been approved for treatment of cutaneous oncologic conditions such as actinic keratosis, Bowen's disease, and superficial basal cell carcinoma. Multicenter, randomized, controlled studies have confirmed its efficacy and superior cosmetic outcomes compared to conventional therapies. Nevertheless, this therapeutic method presents some adverse effects, such as erythema, edema, pigmentation, pustules, and pain. There is no doubt that pain is the most severe of the adverse effects, being sometimes responsible for definitive treatment interruption. The pain mechanism has not yet been fully understood, which makes complete pain control a challenge to be conquered. In spite of that, this literature review presents some useful pain management strategies as well as the most important pain-related factors in photodynamic therapy.
\end{abstract}

Keywords: Pain, referred; Photochemotherapy; Photosensitizing agents

Resumo: A terapia fotodinâmica consiste na administração de uma droga fotossensibilizante e sua subseqüente irradiação com uma fonte de luz de espectro correspondente ao do seu fotossensibilizador. Em diversos países do mundo, a terapia fotodinâmica tópica é aprovada para o tratamento de condições oncológicas cutâneas como queratoses actínicas, doença de Bowen e carcinoma basocelular superficial. Estudos multicêntricos controlados e randomizados confirmam sua eficácia e seus resultados cosméticos superiores em relação às terapias convencionais. No entanto, existem alguns efeitos adversos inerentes a esse método terapêutico, como eritema, edema, pigmentação, pústulas e dor. Essa última é, sem dúvida, a mais importante deles, chegando a ser responsável pela interrupção definitiva do tratamento em alguns casos. O mecanismo dessa dor permanece ainda não completamente entendido. Tal fato faz do controle total da dor durante a terapia fotodinâmica um desafio ainda a ser conquistado. Apesar disso, esta revisão apresenta algumas estratégias que podem ajudar os pacientes a tolerar melhor a terapia fotodinâmica, além de relacionar os principais fatores ligados à dor descritos na literatura.

Palavras-chave: Agentes fotossensibilizantes; Dor referida; Fotoquimioterapia

Received on 08.02.2011.

Approved by the Advisory Board and accepted for publication on 20.05.2011

Study conducted at the Tumor Outpatient Clinic, Department of Dermatology, School of Medicine, University of Sao Paulo (USP) - Sao Paulo (SP), Brazil. Conflict of interest: None

Financial funding: None

MSc student, Department of Dermatology, School of Medicine, University of Sao Paulo (USP) - Sao Paulo (SP), Brazil.

$\mathrm{PhD}$ in Dermatology - Graduate student, Department of Dermatology, School of Medicine, University of Sao Paulo (USP) - Sao Paulo (SP), Brazil.

Graduate student, Department of Dermatology, School of Medicine, University of Sao Paulo (USP) - Sao Paulo (SP), Brazil.

Professor, Department of Dermatology, School of Medicine, University of Sao Paulo (USP) - Sao Paulo (SP), Brazil.

Professor - Full Professor, Department of Dermatology, School of Medicine, University of Sao Paulo (USP) - Sao Paulo (SP), Brazil. 


\section{INTRODUCTION}

Photodynamic therapy (PDT) is a therapeutic method used for treatment of actinic keratoses, Bowen's disease, field cancerization, superficial basal cell carcinoma, and thin nodular basal cell carcinoma. It consists in the light activation of a photosensitizing agent, which selectively accumulates in preneoplastic and neoplastic tissues to generate reactive oxygen intermediates. These intermediates irreversibly oxidize essential cellular components causing tissue damage and necrosis. ${ }^{1,2}$ It is extremely safe, effective, and produces excellent cosmetic results with few adverse effects. ${ }^{3}$ Pain, edema, erythema, pigmentation, and pustules are among the main complications, with pain being the most important one. ${ }^{4,5}$

Pain assessment is extremely difficult due to great interpersonal variation and the psychosocial factor inherent in it. During PDT, pain often manifests as a burning sensation and usually peaks in the first minutes of treatment, tending to stabilize or even decrease by the end of it. ${ }^{6}$ The Visual Analogue Scale (VAS) is the most widely used method to measure pain, in which the patient indicates their pain intensity on a scale of zero to ten. Most studies agree that about twenty percent of the patients undergoing PDT rate pain over six on this scale, which is considered an important level. ${ }^{5,7,8}$

The mechanism of action of pain in PDT has not yet been elucidated. It is thought that nerve stimulation plays a major role through receptors located at the endings of myelinated A delta fibers and unmyelinated $\mathrm{C}$ fibers. ${ }^{9}$ Inflammation caused by cell necrosis can also be decisive, particularly when pain persists after the end of the sessions. Hyperthermia remains a controversial factor. Orenstein et al. showed that, during PDT, patients reported pain in the arm where the photosensitizer had been applied and not in the other one, where the photosensitizer had not been applied, even using similar temperatures and radiation. ${ }^{10}$ However, it is theorized that some pain receptors would only be activated in the presence of hyperthermia combined with inflammation. The latter induced by photochemical reaction in the presence of the photosensitizing agent. ${ }^{11}$

\section{FACTORS RELATED TO PAIN IN PDT}

In an attempt to identify cases with a greater predisposition to pain, several factors were related to it. These factors were type of photosensitizer, location, extent and type of lesion, fluence, irradiance, types of light source, number of sessions, and skin phototypes.

\section{TYPE OF PHOTOSENSITIZER (5-ALA VERSUS METHYL ALA)}

In most studies, MAL-PDT appears to be less painful than ALA-PDT. ${ }^{12-15}$ It is important to clarify some differences in the mechanism of action of these substances. ALA appears to be less selective for abnormal cells than MAL, which may lead to a great accumulation of protoporphyrin IX (PpIX), even in normal cells. ${ }^{16,17}$ Wiegell et al. found no difference in pain between MAL-PDT and ALA-PDT in the treatment of acne and actinic keratoses when differences in the accumulation of PpIX, measured by fluorescence, were corrected.$^{18}$ It is believed that ALA, unlike MAL, is transported into nerve endings by gamma-aminobutyric acid receptors, which could precipitate painful stimuli (Table 1) ${ }^{14}$

\section{LOCATION, TYPE AND EXTENT}

Lesions in areas of rich innervation, such as the head, hands, and perineum, seem to cause more pain, as well as larger lesions. ${ }^{5,719}$ Regarding the type of lesion, actinic keratoses have been reported as more painful than Bowen's disease and basal cell carcinoma. ${ }^{5}$ Plaques of psoriasis are the ones that reach higher levels of pain. ${ }^{20,21}$ Acne can also produce significant pain with both ALA and MAL-PDT, at levels higher than those achieved when using only light irradiation. ${ }^{22,23}$ Pain was measured during ALA-PDT to treat verruca vulgaris, and not only high levels, but also long time duration of an average of thirty-six hours was observed. ${ }^{24}$ Sandberg et al. noted that the erythema, in addition to the extent, was significantly related to pain during the treatment of actinic keratoses. In the same study, erythema was also related to reduction of the area with actinic keratosis and to cure rate. ${ }^{7}$

\section{IRRADIANCE AND TOTAL DOSE OF LIGHT (FLUENCE)}

We must first distinguish between irradiance or fluence rate, measured in $\mathrm{MW} / \mathrm{cm}^{2}$ and fluence or total dose, measured in $\mathrm{J} / \mathrm{cm}^{2}$. Irradiance is inversely proportional to the distance between the light source and the treated area, and fluence corresponds to the product of irradiance and time in seconds. ${ }^{3}$ Most studies show that the greater the fluences and irradiances, the higher the levels of pain. ${ }^{8,20,25,26,27}$ Only one study found no relationship between pain and irradiance. ${ }^{28}$ In that study, irradiances of thirty to seventyfive $\mathrm{mW} / \mathrm{cm}^{2}$ were tested in the treatment of actinic keratoses. Even so, both PpIX photobleaching and clinical results were better under low irradiance.

\section{LIGHT SOURCE AND LENGTH}

The data regarding this topic are very inconsistent. Incoherent light sources, continuous-wave laser 
TABLE 1: Type of photosensitizer (5-ALA VERSUS METHYL ALA)

\begin{tabular}{lll}
\hline Study & $\begin{array}{l}\text { Diagnosis } \\
\text { (Number of patients) }\end{array}$ & Results \\
\hline Kasche et al, 2006 & AK (69) & ALA > MAL \\
Moloney and Collins, 2007 & AK (16) & ALA MAL \\
Kuijpers et al, 2006 & BCC (39) & ALA $=$ MAL \\
Wiegell et al, 2003 & Photoexposed healthy skin (20) & ALA $>$ MAL \\
Wiegell and Wulf, 2006 & Acne and AK (15) & ALA $=$ MAL \\
Arits et al, 2010 & BCC, AK and BD (108) & ALA $=$ MAL \\
\hline
\end{tabular}

or pulsed light sources have already been used. The ideal type of light for PDT should have the following characteristics: high absorption by the photosensitizer; high skin penetration; appropriate fluence and duration; little pain, and good cosmetic result. ${ }^{29}$ In 2007, Babilas et al. compared a pulsed light (VPL) with a Light Emitting Diode (LED) and showed that pulsed light was less painful than LED in MAL-PDT, even using higher total fluence. This can be explained by the short duration of the pulse, which was five milliseconds, totaling 355 milliseconds at the end of the treatment. ${ }^{30}$ The restricted time of exposure of the photosensitizer to pulsed light may not be enough for complete activation of the PpIX molecules, which theoretically can decrease effectiveness with this light source. Further comparative studies on the effectiveness of PDT with pulsed light are needed for better analysis of this topic. A trend toward less pain in PDT with green light, in comparison with red light, has been reported in the treatment of Bowen's disease, although the green light has presented reduced effectiveness. ${ }^{31}$ Conventional MAL-PDT using LED was compared with continuous activation of MAL by sunlight for treatment of actinic keratoses on the scalp and forehead. ${ }^{32}$ Continuous activation produced lower levels of pain, possibly due to the fact that the sunlight has lower irradiance than LED. This study deserves some criticism for treating premalignant lesions with potentially carcinogenic UV radiation, for the absence of a specific spectrum of light, and because continuous activation of MAL interferes with appropriate accumulation of the photosensitizer in the deeper layers of the skin, thus preventing treatment of deeper lesions. A more recent study compared LED (AKTLI$\mathrm{TE}$ ) with a halogen lamp, which emits visible light plus a filter for infrared light (HYDROSUN TYPE 505) and found lower maximum levels of pain when using the latter in the treatment of actinic keratoses. ${ }^{33}$ This difference was only observed in the group that did not use cold water spray during treatment.

\section{FLUORESCENCE}

Fluorescence can be easily observed with the aid of a Wood's lamp in routine medical practice.
Measurement of this fluorescence is, however, extremely difficult, causing discrepancies among the studies on this topic. Fluorescence reflects the concentration of PpIX in the skin. The onset of pain during PDT was related to the concentration of PpIX, measured through fluorescence. This onset occurred with photobleaching of 50-60\% of PpIX derived from ALA and of $35-45 \%$ of PpIX derived from MAL. ${ }^{34}$ Photobleaching of PpIX in turn, depends on the amount of singlet oxygen that will be formed and that will be directly responsible for cell damage. ${ }^{35}$ Given that the rate of oxygen consumption is proportional to the product of concentration of PpIX (fluorescence) and irradiance, we may conclude that pain is related to oxygen consumption, fluorescence and irradiance. ${ }^{27,34}$ Wiegell et al. also showed a direct relationship between pain and fluorescence and irradiance in a study that dealt with acne and actinic keratoses with MAL-PDT. ${ }^{26}$ Moreover, they concluded that there was no relationship between pain and location or type of lesions after correction of fluorescence. The results found by the authors of this study corroborate that higher fluorescence cause higher levels of pain.

\section{NUMBER OF SESSIONS}

There is one study showing that the second session of PDT tends to be more painful than the first one in most cases. The first session can serve as a predictor of pain for the second session, since patients with scores lower than five in the first session would have more pain during the second session and vice versa. The reason for this fact has not yet been clarified. ${ }^{36}$

\section{SKIN PHOTOTYPES}

A prospective study treated 141 lesions in 108 patients, including BCCs, Bowen's disease and actinic keratoses. ${ }^{37}$ After correcting the factors associated with high levels of pain, the only independent factor associated with pain was skin phototypes 1 and 2 . This study did not take fluorescence of the lesions into account and proposed as an explanation to this result the fact that skin with higher concentrations of melanin presents lower light penetration, resulting in less formation of singlet oxygen and less tissue damage. 


\section{PAIN MANAGEMENT DURING PHOTODYNAMIC THERAPY}

The perception of pain occurs due to nociceptors located at the nerve endings of thin myelinated A delta fibers and unmyelinated $\mathrm{C}$ fibers. The action potential is generated when these nerve endings are stimulated. ${ }^{9}$ Propagation of this impulse may occur directly through potassium ions or specific molecules which accumulate during tissue damage, such as histamine, bradykinin, serotonin, and prostaglandins (substances found in mast cells, which can be degranulated by activated porphyrin molecules). ${ }^{38}$

Several strategies for controlling pain during PDT have been studied. Although some of them achieve a reduction in levels of pain, none was completely effective. The challenge of controlling pain during PDT involves first a complete understanding of its real mechanism, which remains unclear. The main methods of pain management in PDT are described below.

\section{THERMAL WATER}

There is only one study in the literature on the use of thermal water in photodynamic therapy. ${ }^{39}$ This study, sponsored by Avène, showed reduction in pain from the third to the sixth day after PDT with Avène thermal spring water and not with thermal water with a high mineral content, when used every 4 hours after each PDT session. Thermal spring water is thought to have an inhibitory activity on mast cell degranulation as well as an anti-inflammatory activity in vitro. ${ }^{40} \mathrm{It}$ is known that intact axons may be directly activated by molecules that accumulate during tissue damage and that they may be the product of mast cell degranulation. ${ }^{41}$ Thus, this inhibitory activity on mast cell degranulation may help control pain. No study on the use of thermal spring water during PDT session and with no conflict of interest was found in the literature.

\section{COLD AIR}

Specific machines for cooling the skin with cold air are increasingly common in medical practice and can be really useful for pain management during PDT.

${ }^{42}$ Cold air can reduce metabolism, which reduces the effects of tissue damage. Cold air also stimulates A delta nerve fibers, which activate the pain inhibitory mechanism and raise its threshold. ${ }^{43}$ The cold and menthol receptor, also known as TRPM8, which promotes analgesia in the early stages of inflammation, is also responsible for pain reduction with cold air. ${ }^{44}$ Regarding the influence of cold air on treatment efficacy, the study that used forced cold air treated 26 patients with non-melanocytic skin cancer and found no recurrence after a follow-up of 6 months. ${ }^{42}$ Another study, however, showed decreased efficacy of PDT in cases of actinic keratoses when cold water spray was used, after a follow-up of six months. ${ }^{33}$ In a recent retrospective, observational, and controlled study, Tyrrell et al. showed decreased bleaching of PpIX when forced cold air was used for analgesia in relation to the control group. Complete clinical cure after 3 months was also reduced. So, forced cold air equipment must be used sparingly, although they are effective options for analgesia during PDT. ${ }^{45}$

\section{TOPICAL ANESTHETICS}

No topical anesthetic showed any efficacy in controlling pain during PDT. A double-blind, randomized, controlled study with 14 patients with actinic keratoses on the forehead showed no significant difference in pain scores, regardless of the use of EMLA or placebo. ${ }^{46}$ In another study with 60 patients, EMLA also showed no benefit. ${ }^{5}$ Another double-blind, randomized, controlled study with 42 patients showed that tetracaine gel 4\% (Ametop) did not significantly reduce pain during or after PDT for small lesions of superficial BCC, Bowen's disease, or actinic keratoses. ${ }^{47}$ Morphine gel $0.3 \%$ also showed no benefit when used in PDT for the treatment of BCC and actinic keratoses. ${ }^{48}$ In a pilot study, after a pretreatment period of a week with topical capsaiscin, for desensitization to substance $\mathrm{P}$, no pain relief during PDT was observed. Furthermore, the use of capsaiscin also caused a burning sensation and pruritus in the sites where it was applied. ${ }^{7}$ Lidocaine 3\% for the management of pain in PDT has been studied and has shown to be ineffective. ${ }^{49} \mathrm{~A}$ possible explanation for the failure of topical anesthetics in PDT is the fact that both ALA and MAL have an acidic $\mathrm{pH}$, while the majority of the topical anesthetics have an alkaline $\mathrm{pH}$, making their combined use incompatible.

\section{INJECTABLE ANESTHETICS}

Both infiltration anesthesia and nerve block proved to be useful in the management of pain in PDT. ${ }^{50.52}$ The use of anesthetics without vasoconstrictor is recommended to allow adequate oxygen supply in the area to be treated, thus ensuring the effectiveness of PDT. Lidocaine, mepivacaine, ropivacaine and tumescent anesthesia have already been used; all with some degree of success in the management of pain. ${ }^{50-}$

${ }^{52}$ Berking et al. used infiltration anesthesia with mepivacaine in the treatment of actinic cheilitis and observed good pain tolerance in these cases. ${ }^{50}$ Tumescent anesthesia with ropivacaine, prilocaine, and epinephrine were used to treat actinic keratoses on the malar region and produced lower levels of pain compared to the isolated use of analgesics. In that study, however, a local edema which lasted from about one to three days was observed. ${ }^{51}$ A study used nerve block with mepivacaine and adrenaline in one half of the 
face for the treatment of actinic keratoses on the whole face. This study shows significantly reduced levels of pain in the half part of the face where the nerve block was applied, with a good level of patient satisfaction. ${ }^{52}$ Serra-Guillen et al. compared cold air and supraorbital and supratrochlear nerve block in the treatment of actinic keratoses of the frontotemporal region and showed that nerve block was more effective than cold air in such cases. ${ }^{53}$

\section{REDUCING IRRADIANCE}

As discussed above, lower irradiances are related to lower levels of pain, and irradiance is inversely proportional to the distance between the light source and the area to be treated. Using a LED red light source (AKTLITE), Wiegell et al. showed that when the distance was increased from the $8 \mathrm{~cm}$ recommended in standard therapy to $25 \mathrm{~cm}$, irradiance fell by half. Knowing that fluence or total dose corresponds to the product of irradiance and time, exposure time must be doubled to maintain the same total dose with half of the irradiance. This way, it is possible to reduce irradiance in a practical and controlled manner, producing lower levels of pain without negatively affecting treatment. $^{26}$

\section{REFERENCES}

1. Morton CA, McKenna KE, Rhodes LE; British Association of Dermatologists Therapy Guidelines and Audit Subcommittee and the British Photodermatology Group. Guidelines for topical photodynamic therapy: update. $\mathrm{Br} \mathrm{J}$ Dermatol. 2008;159:1245-66.

2. Grapengiesser S, GudmundssonF, Larkö 0, Ericson M, Rósen A, Wennberg AM. Pain caused by photodynamic therapy in skin cancer. Clin Exp Dermatol. 2002:27:493-7.

3. Ericson MB, Sandberg C, Stenquist B, Gudmundson F, Karlsson M, Ros AM, et al. Photodynamic therapy of actinic keratosis at varying fluence rates: assessment of photobleaching, pain and primary clinical outcome. $\mathrm{Br} J$ Dermatol. 2004;151:1204-12.

4. Sandberg C, Stenquist B, Rosdahl I, Ros AM, Synnerstad I, Karlsson M, et al. Important factors for pain during photodynamic therapy for actinic keratosis. Acta Derm Venereol. 2006;86:404-8

5. Clark C, Bryden A, Dawe R, Moseley H. Ferguson J, Ibbotson SH. Topical 5-aminolaevulinic acid photodynamic therapy for cutaneous lesions: outcome and comparison of light sources. Photodermatol Photoimmunol Photomed. 2003;19:13441.

6. Siddall PJ, Cousins MJ. Neurobiology of pain. Int Anesthesiol Clin. 1997;35:1-26.

7. Orenstein A, Kostenich G, Tisur H, Kogan L, Malik Z. Temperature monitoring during photodynamic therapy of skin tumors with topical 5-aminolevulinic acid application. Cancer Lett. 1995;93:227-32.

8. Mandadi S, Tominaga T, Numazaki M, Murayama N, Saito N, Armati PJ, et al. Increased sensitivity of desensitized TRPV1 by PMA occurs through PKCepsilonmediated phosphorylation at S800. Pain. 2006;123:106-16.

9. Kasche A, Luderschmidt S, Ring J, Hein R. Photodynamic therapy induces less pain in patients treated with methyl aminolevulinate compared to aminolevulinic acid. J Drugs Dermatol. 2006;5:353-6.

10. Moloney FJ, Collins P. Randomized, double-blind, prospective study to compare topical 5-aminolevulinic acid methylester with topical 5-aminolevulinic acid photodynamic therapy for extensive scalp actinic keratosis. $\mathrm{Br} \mathrm{J}$ Dermatol. 2007:157:87-91.

\section{INTERRUPTION OF SESSIONS}

It has been shown that after interrupting PDT for an interval of 3 minutes using cold water spray to cool the area, a significant reduction in pain levels without interfering with the rate of protoporphyrin IX bleaching was observed. ${ }^{54}$ The reduced pain levels achieved during this interruption could be maintained if cold water spray continued to be used during the second part of the session. In that study, follow-up after the PDT sessions was not carried out, thus not allowing for analysis of inflammation or of the rate of cure after sessions.

\section{CONCLUSION}

Photodynamic therapy is a safe and effective method of treatment that produces excellent cosmetic results, when indicated properly. One of the main obstacles to using this method is the pain caused by it. The mechanism of this pain has not yet been completely understood. This fact makes total pain management during PDT a challenge to be conquered. Nevertheless, this literature review presents some strategies that can help patients better tolerate photodynamic therapy. It also addresses the main factors related to pain during PDT described in the literature.
11. Wiegell SR, Stender IM, Na R, Wulf HC. Pain associated with photodynamic therapy using 5-aminolevulinic acid or 5- aminolevulinic acid methylester on tape-stripped normal skin. Arch Dermatol. 2003;139:1173-7.

12. Wiegell SR, Wulf HC. Photodynamic therapy of acne vulgaris using 5-aminolevulinic acid versus methyl aminolevulinate. J Am Acad Dermatol. 2006:54:647-51.

13. Kuijpers DI, Thissen MR, Thissen CA, Neumann MH. Similar effectiveness of methyl aminolevulinate and 5-aminolevulinate in topical photodynamic therapy for nodular basal cell carcinoma. J Drugs Dermatol. 2006;5:642-5.

14. Fritsch C, Homey B, Stahl W, Lehmann P, Ruzicka T, Sies H. Preferential relative porphyrin enrichment in solar keratoses upon topical application of delta-aminolevulinic acid methylester. Photochem Photobiol. 1998;68:218-21.

15. Fritsch C, Stege H, Saalmann G, Goerz G, Ruzicka T, Krutmann J. Green light is effective and less painful than red light in photodynamic therapy of facial solar keratoses. Photodermatol Photoimmunol Photomed. 1997;13:181-5.

16. Radakovic-Fijan S, Blecha-Thalhammer U, Schleyer V, Szeimies RM, Zwingers T, Hönigsmann $\mathrm{H}$, et al. Topical aminolevulinic acid-based photodynamic therapy as a treatment option for psoriasis? Results of a randomized, observer-blinded study. Br J Dermatol. 2005;152:279-83.

17. Schleyer V, Radakovic-Fijan S, Karrer S, Zwingers T, Tanew A, Landthaler M, et al. Disappointing results and low tolerability of photodynamic therapy with topical 5aminolevulinic acid in psoriasis: a randomized, double-blind phase $\mathrm{I} / \mathrm{II}$ study. J Eur Acad Dermatol Venereol. 2006;20:823-8.

18. Wiegell SR, Wulf HC. Photodynamic therapy of acne vulgaris using methyl aminolevulinate: a blinded, randomized, controlled trial. Br J Dermatol. 2006;154:969-76

19. Horfelt C, Funk J, Frohm-Nilsson M, Wiegleb Edstrom D, Wennberg AM. Topical methyl aminolevulinate photodynamic therapy for treatment of facial acne vulgaris: results of a randomized, controlled study. Br J Dermatol. 2006;155:608-13.

20. Stender IM, Na R, Fogh H, Gluud C, Wulf HC. Photodynamic therapy with 5-aminolevulinic acid or placebo for recalcitrant foot and hand warts: randomized double-blind trial. Lancet. 2000;355:963-6. 
21. Radakovic-Fijan S, Blecha-Thalhammer U, Kittler H, Hönigsmann H, Tanew A Efficacy of 3 different light doses in the treatment of actinic keratosis with 5-aminolevulinic acid photodynamic therapy: a randomized, observer-blinded, intrapatient, comparison study. J Am Acad Dermatol. 2005;53: 823-7.

22. Ericson MB, Sandberg C, Stenquist B, Gudmundson F, Karlsson M, Ros AM, et al. Photodynamic therapy of actinic keratosis at varying fluence rates: assessment of photobleaching, pain and primary clinical outcome. $\mathrm{Br} J$ Dermatol. 2004;151:1204-12.

23. Wiegell SR, Skiveren J, Philipsen PA, Wulf HC. Pain during photodynamic therapy is associated with protoporphyrin IX fluorescence and fluence rate. $\mathrm{Br} J$ Dermatol. 2008;158:727-33.

24. Cottrell WJ, Paquette AD, Keymel KR, Foster TH, Oseroff AR. Irradiance-dependent photobleaching and pain in delta-aminolevulinic acid-photodynamic therapy of superficial basal cell carcinomas. Clin Cancer Res. 2008;14:4475-83.

25. Alexiades-Armenakas M. Laser-mediated photodynamic therapy. Clin Dermatol. 2006;24:16-25

26. Babilas P, Knobler R, Hummel S, Gottschaller C, Maisch T, Koller M, et al. Variable pulsed light is less painful than light-emitting diodes for topical photodynamic therapy of actinic keratosis: a prospective randomized controlled trial. $\mathrm{Br} \mathrm{J}$ Dermatol. 2007;157:111-7.

27. Morton CA, Whitehurst C, Moore JV, MacKie RM. Comparison of red and green light in the treatment of Bowen's disease by photodynamic therapy. Br J Dermatol. 2000;143:767-72.

28. Wiegell SR, Haedersdal M, Philipsen PA, Eriksen P, Enk CD, Wulf HC. Continuous activation of PpIX by daylight is as effective as and less painful than conventional photodynamic therapy for actinic keratoses; a randomized, controlled, single-blinded study. Br J Dermatol. 2008;158:740-6.

29. Mikolajewska P, Iani V, Juzeniene A, Moan J. Topical aminolaevulinic acid- and aminolaevulinic acid methyl ester-based photodynamic therapy with red and violet light: influence of wavelength on pain and erythema. $\mathrm{Br} J$ Dermatol. 2009;161:1173-9.

30. Dysart JS, Singh G, Patterson MS. Calculation of singlet oxygen dose from photosensitizer fluorescence and photobleaching during mTHPC photodynamic therapy of MLL cells. Photochem Photobiol. 2005;81:196-205.

31. Lindeburg KEK, Brogaard HMV, Jemec GBE. Pain and photodynamic therapy. Dermatology. 2007;215:206-8.

32. Goldman MP, Merial-Kieny C, Nocera T, Mery S. Comparative benefit of two thermal spring waters after photodynamic therapy procedure. J Cosm Dermatol. 2007:6:31-5.

33. Joly F, Galoppin L, Bordat P, Cousse H, Neuzil E. Calcium and bicarbonate ions mediate the inhibition of mast cell histamine release by Avene spa water. Fundam Clin Pharmacol. 2000;14:611-3.

34. Glover RA, Bailey CS, Barrett KE, Wasserman SI, Gigli I. Histamine release from rodent and human mast cells induced by protoporphyrin and ultraviolet light: studies of the mechanism of mast-cell activation in erythropoietic protoporphyria. $\mathrm{Br}$ J Dermatol. 1990;122:501-12.

35. Pagliaro J, Elliott T, Bulsara M, King C, Vinciullo C. Cold air analgesia in photodynamic therapy of basal cell carcinomas and Bowen's disease: an effective addition to treatment; a pilot study. Dermatol Surg. 2004;30:63-6.

36. Leff DR, Nortley M, Dang V, Bhutiani RP. The effect of local cooling on pain perception during infiltration of local anesthetic agents, a prospective randomized controlled trial. Anaesthesia. 2007;62:677-82.

37. Voets T, Droogmans G, Wissenbach U, Janssens A, Flockerzi V, Nilius B. The principle of temperature-dependent gating in cold- and heat-sensitive TRP channels. Nature. 2004:430:748-54.

38. Langan SM, Collins P. Randomized, double-blind, placebo controlled prospective study of the efficacy of topical anesthesia with a eutectic mixture of lignocaine $2.5 \%$ and prilocaine $2.5 \%$ for topical 5 -aminolevulinic acid-photodynamic therapy for extensive scalp actinic keratoses. Br J Dermatol. 2006;154:146-9.

39. Holmes MV, Dawe RS, Ferguson J, Ibbotson SH. A randomized, double-blind, placebo-controlled study of the efficacy of tetracaine gel (Ametop) for pain relief during topical photodynamic therapy. Br J Dermatol. 2004;150:337-40.
40. Skiveren J, Haedersdal M, Philipsen PA, Wiegell SR, Wulf HC. Morphine gel $0.3 \%$ does not relieve pain during topical photodynamic therapy: a randomized, doubleblind, placebo- controlled study. Acta Derm Venereol. 2006;86:409-11.

41. Touma D, Yaar M, Whitehead S, Konnikov N, Gilchrest BA. A trial of short incubation, broad-area photodynamic therapy for facial actinic keratoses and diffuse photodamage. Arch Dermatol. 2004;140:33-40.

42. Berking C, Herzinger T, Flaig MJ, Brenner M, Borelli C, Degitz K. The efficacy of photodynamic therapy in actinic cheilitis of the lower lip: a prospective study of 15 patients. Dermatol Surg. 2007;33:825-30.

43. Borelli C, Herzinger T, Merk K, Berking C, Kunte C, Plewig G, et al. Effect of subcutaneous infiltration anesthesia on pain in photodynamic therapy: a controlled open pilot trial. Dermatol Surg. 2007;33:314-8.

44. Paoli J, Halldin C, Ericson MB, Wennberg AM. Nerve blocks provide effective pain relief during topical photodynamic therapy for extensive facial actinic keratoses. Clin Exp Dermatol. 2008;33:559-64

45. Serra-Guillen C, Hueso L, Nagore E, Vila M, Llombart B, Requena Caballero C, et al. Comparative study between cold air analgesia and supraorbital and supratrochlear nerve block for the management of pain during photodynamic therapy for actinic keratoses of the frontotemporal zone. Br J Dermatol. 2009;161:353-6.

46. Wiegell SR, Haedersdal M, Wulf HC. Cold water and pauses in illumination reduces pain during photodynamic therapy: a randomized clinical study. Acta Derm Venereol. 2009;89:145-9.

47. Arits AH, van de Weert MM, Nelemans PJ, Kelleners-Smeets NW. Pain during topical photodynamic therapy: uncomfortable and unpredictable. J Eur Acad Dermatol Venereol. 2010;24:1452-7.

48. von Felbert V, Hoffmann G, Hoff-Lesch S, Abuzahra F, Renn CN, Braathen LR, et al. Photodynamic therapy of multiple actinic keratoses: reduced pain through use of visible light plus water-filtered infrared $A$ compared with light from light-emitting diodes. Br J Dermatol. 2010;163:607-15.

49. Glover RA, Bailey CS, Barrett KE, Wasserman SI, Gigli I. Histamine release from rodent and human mast cells induced by protoporphyrin and ultraviolet light: studies of the mechanism of mast-cell activation in erythropoietic protoporphyria. $\mathrm{Br}$ J Dermatol. 1990;122:501-12.

50. Torezan L, Niwa AB, Festa Neto C. Terapia fotodinâmica em dermatologia: princípios básicos e aplicações. An Bras Dermatol. 2009;84:445-59.

51. Bakos MR, Bakos L, Felin E, Cestari TF, Orlandini T, Rezende RL, Peukert C, Berti $\mathrm{CB}$, Domenico ED. Terapêutica fotodinâmica com ácido delta-aminolevulínico em neoplasias queratinocíticas superficiais. An Bras Dermatol. 2003;78:197-207.

52. Tyrrell J, Campbell SM, Curnow A. The effect of air cooling pain relief on protoporphyrin IX photobleaching and clinical efficacy during dermatological photodynamic therapy. J Photochem Photobiol B. 2011;103:1-7.

53. Neves DR, Ramos DG, Magalhães GM, Rodrigues RC, Souza JBA. Terapia fotodinâmica para tratamento de múltiplas lesões no couro cabeludo na síndrome do nevobasocelular - Relato de caso. An Bras Dermatol. 2010,85:545-8.

54. Issa MCA, Manela-Azulay M. Terapia fotodinâmica: revisão da literatura e documentação iconográfica. An Bras Dermatol. 2010;85:501-11.

How to cite this article: Chaves YN, Torezan LA, Niwa ABM, Sanches JA Jr, Festa Neto C. Pain in photodynamic therapy: mechanism of action and management strategies. An Bras Dermatol. 2012;87(4):521-9. 


\section{QUESTIONS}

1 - Knowledge of the dynamics of pain during photodynamic therapy is essential for the physician to prepare the patient and leave him/her more relaxed during the sessions. Regarding pain in photodynamic therapy, it is correct to state the following:

a) Pain starts at the time of application of the photosensitizer and increases until the end of the period of irradiation, when it subsides completely.

b) Pain tends to peak in the first minutes of irradiation and tends to decrease or stabilize by the end of the session. After the session, there may be lower levels of pain, which may last up to 36 hours. c) Higher levels of pain tend to manifest after irradiation due to the intense necrosis and inflammatory reaction generated during PDT and may last up to 7 days.

d) Photodynamic therapy maintains pain levels constant and higher during irradiation. After the sessions, the pain tends to decrease, stopping within at most 24 hours.

2 - The mechanism of pain in PDT has not yet been fully understood, but there are several important theories. Regarding the mechanism of pain during PDT, it is correct to state the following:

a) Stimulation of specific nerve endings, inflammation, and hyperthermia must be involved.

b) Inflammation caused during PDT is minimal and, therefore, it does not influence the mechanism of pain.

c) A decisive factor in the mechanism of pain during PDT is local increased temperature, since pain increases proportionally to the increase in temperature, irrespective of other factors.

d) It is thought that nerve stimulation plays a major role through receptors located at the endings of myelinated $\mathrm{C}$ fibers and unmyelinated A delta fibers.

3 - Some studies have listed factors associated with pain during PDT. Which of the following statements is true regarding those factors?

a) According to most studies, ALA-PDT appears to be less painful than MAL-PDT, possibly because MAL, unlike ALA, is transported into nerve endings through gamma-aminobutyric receptors, which could precipitate painful stimuli.

b) Lesions in areas of rich innervation, such as the head, hands and perineum, seem to cause more pain, as well as larger lesions.

c) Basal cell carcinomas and Bowen's disease were reported as being more painful than actinic keratoses, which shows that the deeper the lesion is, the greater the likelihood to present pain.

d) Treatment of plaques of psoriasis with PDT shows irrelevant levels of pain. Thus, pain in these cases is not a significant adverse effect.
4 - The concepts of irradiance and fluorescence must be well understood, since they are important factors related to pain in PDT. It is correct to state the following about these factors:

a) Fluence corresponds to the product of irradiance and time in seconds.

b) Irradiance is inversely proportional to the distance between the light source and the area treated. c) Irradiance or fluence rate, measured in $\mathrm{mW} / \mathrm{cm}^{2}$, and fluence or total dose, measured in $\mathrm{J} / \mathrm{cm}^{2}$.

d) All of the above are correct.

5 - Various types of light sources have been studied in photodynamic therapy. Which of the characteristics below would make a light source ideal for PDT?

a) High absorption by the photosensitizer and low skin penetration.

b) High fluence and short duration.

c) Produce little pain and good cosmetic result.

d) Alternatives "a" and "c".

6 - Regarding the different sources of light during PDT, it is correct to state the following:

a) Pulsed light seems to be a light source less painful than LED. However, the short exposure time of the photosensitizer can compromise treatment effectiveness.

b) Green light not only shows to be less painful than red light in the treatment of Bowen's disease, but also more effective.

c) Continuous activation of the photosensitizer by sunlight is more painful than conventional MAL-PDT.

d) All of the statements above are true.

7 - A recent study has compared conventional MAL-PDT to continuous activation of MAL by sunlight. This method is subject to some criticism. Among the options below, choose the one that does not apply to continuous activation of MAL by sunlight:

a) It treats premalignant lesions with potentially carcinogenic UV radiation

b) It causes higher levels of pain than conventional MAL-PDT

c) It prevents proper accumulation of the photosensitizer in the deeper layers of the epidermis d) It does not have a specific spectrum of light

8 - Regarding factors related to pain in PDT, check the wrong alternative below.

a) The higher fluorescence is, the higher the levels of pain experienced by patients tend to be.

b) The second PDT session tends to be less painful than the first one in most cases.

c) Irradiance is directly proportional to levels of pain during PDT.

d) Higher skin phototypes appear to present lower levels of pain due to less penetration of light as a result of higher concentration of melanin. 
9 - One of the options for pain management during PDT is the use of cold air. Regarding this option, it is correct to state the following:

a) Cold air can reduce metabolism, which reduces the effects of tissue damage.

b) Cold air stimulates A delta nerve fibers, which activate the inhibitory mechanism of pain and raise pain threshold

c) The cold and menthol receptor, known as TRPM8, promotes analgesia in the early stages of inflammation.

d) All of the statements above are right.

10 - Regarding the use of topical anesthetics during PDT, check the correct alternative below.

a) Topical anesthetics are an effective and easy-to-use alternative to control pain during PDT.

b) Both ALA and MAL have an alkaline $\mathrm{pH}$, while most topical anesthetics have an acidic $\mathrm{pH}$, making the combined use of these substances incompatible. c) Most topical anesthetics do not interfere with the effectiveness of PDT, since they have a $\mathrm{pH}$ similar to that of the main photosensitizers.

d) Although they are effective in controlling pain, topical anesthetics should not be used because their $\mathrm{pH}$ is different from that of the photosensitizers.

11 - Regarding the use of injectable anesthetics during PDT, check the correct alternative below.

a) It is recommended to use anesthetics with vasoconstrictor to minimize bleeding, which may diminish activation of PpIX.

b) Tumescent anesthesia proved to be an ineffective method of analgesia during PDT for preventing adequate penetration of light.

c) In the treatment of actinic keratoses of the frontotemporal region, nerve block was more effective than cold air in the management of pain.

d) All of the statements above are true.

12 - One way to manage pain during PDT is to change irradiance so that pain is relieved. Regarding this subject, check the correct alternative below.

a) One of the strategies to decrease pain levels during PDT is to decrease the distance between the light source and the irradiated surface.

b) The smaller the distance between the light source and the skin is, the lower the irradiance.

c) Increasing the distance between the light source and the skin lowers irradiation during PDT.

d) When irradiance is decreased, time of exposure should be decreased to maintain the same fluence.

13 - When evaluating pain during PDT, there are some important factors to be considered. Which of the statements below is true?

a) About $20 \%$ of the patients undergoing PDT rate pain levels above 8 , which is considered a significant level of pain.

b) Pain during PDT is usually of a throbbing type and peaks at the end of the sessions.

c) The Visual Analogue Scale (VAS) is the most widely used method to measure pain during PDT sessions.

d) All of the statements above are true.
14 - Regarding Photodynamic Therapy, check the correct statement below:

a) Actinic keratoses, Bowen's disease and nodular basal cell carcinomas with more than $2 \mathrm{~mm}$ are excellent treatment options.

b) Pain is not usually an important factor among the adverse effects of photodynamic therapy.

c) It consists in the light activation of a photosensitizing agent, which selectively accumulates in preneoplastic and neoplastic tissues to produce reactive oxygen intermediates.

d) It consists in the light activation of a photosensitizing agent, which accumulates in neoplastic and nonneoplastic tissues to produce reactive oxygen intermediates.

15 - The main photosensitizing agents used in PDT are aminolevulinic acid (ALA) and its methylester (MAL). Regarding these agents, check the correct statement below.

a) ALA is less selective for neoplastic and preneoplastic cells than MAL.

b) ALA is more selective than MAL for neoplastic cells.

c) MAL, unlike ALA, is transported by gammaaminobutyric receptors into nerve endings, which may explain the higher levels of pain achieved with this substance.

d) There is no difference in accumulation of protoporphyrin IX (PpIX) between non-neoplastic and neoplastic cells with the use of both agents.

16 - Fluorescence can be an important factor in predicting levels of pain during PDT sessions. Regarding this subject, check the correct alternative below.

a) Fluorescence reflects the concentration of PpIX in the skin.

b) PpIX photobleaching depends on the amount of singlet oxygen that will be formed and that will be directly responsible for cell damage.

c) The rate of oxygen consumption is proportional to the product of concentration of $\mathrm{PpIX}$ and irradiance.

d) All of the statements above are true.

17 - It is sometimes necessary to interrupt a PDT session upon the patient's request due to pain. Regarding these interruptions, check the correct alternative below.

a) If the session is interrupted, it should not be resumed due to the risk of reduced efficacy of PDT.

b) Once started, the session should not be interrupted under any circumstances.

c) Interruption of a PDT session for a few minutes is a strategy that can be used to help patients better tolerate the pain.

d) Interruption of the sessions does not help in controlling pain. In fact, it prolongs the pain reported by the patient. 
18 - In relation to the management of pain in photodynamic therapy, it is correct to state the following:

a) PDT is a therapeutic method which is safe and effective and which produces minimal levels of pain, thus not requiring any resources for its management. b) Although the mechanism of pain in PDT has been fully clarified, a completely effective method for the management of pain has not been found yet.

c) Although there is no completely effective method for the management of pain, some strategies are important to help patients better tolerate it.

d) Using topical anesthetics, pain management can be done simply, effectively, and without compromising the effectiveness of PDT.

19 - In case a patient reports significant pain during a PDT session, which attitude would be less suitable?

a) Interrupt the session for about 3 minutes, use cold water spray, and then try to resume irradiation. b) Continue the session and combine it with the application of forced cold air.

c) Interrupt the session, apply topical anesthetic for 30 minutes, and resume the session from the beginning. d) Interrupt the session, use nerve block or infiltration anesthesia, and continue the session.

20 - Which of the following lesions would probably produce greater levels of pain?

a) Bowen's disease on the arm with $3 \mathrm{~mm}$ in diameter.

b) Field cancerization with actinic keratoses on the whole forehead.

c) Superficial basal cell carcinoma on the leg.

d) Isolated hypertrophic actinic keratosis on the scalp.

\section{Spitz Naevus and Reed Naevus}

2012;87(3):349-59.

$\begin{array}{lllllll}\text { 1. } & \mathrm{C} & 6 . & \mathrm{C} & 11 . \mathrm{D} & 16 . \mathrm{D} \\ \text { 2. } & \mathrm{D} & 7 . & \mathrm{B} & 12 . \mathrm{D} & 17 . \mathrm{C} \\ \text { 3. } & \mathrm{D} & 8 . & \mathrm{A} & 13 . \mathrm{C} & 18 . \mathrm{B} \\ \text { 4. } & \mathrm{D} & 9 . & \mathrm{B} & 14 . \mathrm{A} & 19 . \mathrm{D} \\ \text { 5. } & \mathrm{B} & 10 . & \mathrm{C} & 15 . \mathrm{D} & 20 . \mathrm{D}\end{array}$

Papers

Information for all members: The EMC$\mathrm{D}$ questionnaire is now available at the homepage of the Brazilian Annals of Dermatology: www.anaisdedermatologia.org.br. The deadline for completing the questionnaire is 30 days from the date of online publication. 